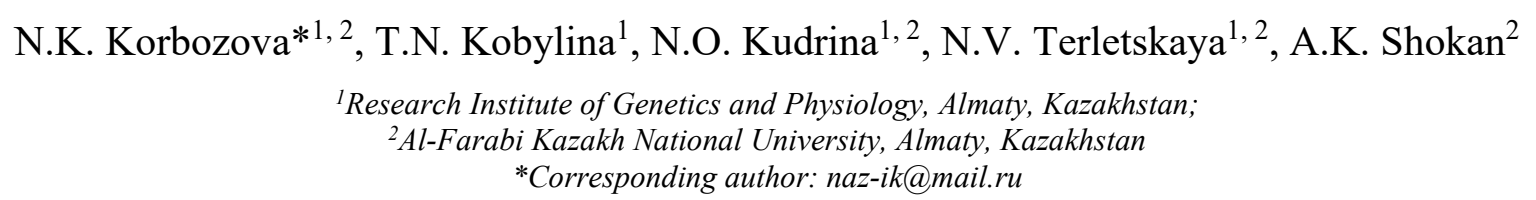

\title{
Effects of Rhodiola semenowii extract on hematological parameters in experimental hypothyreosis
}

\begin{abstract}
Thyroid pathology has a leading position in clinical endocrinology. Diseases of the thyroid gland in terms of prevalence are comparable with diabetes mellitus, and far ahead of other endocrine disorders. Current treatment approaches of hypothyroidism are rarely based on the pathogenesis, and are reduced to hormone replacement therapy. The purpose of this study is to determine the general hematological parameters after correction of experimental hypothyroidism with an extract of the root of the plant $R$. semenowii both alone and in combination with potassium iodide. As a result of the study, we found that in the experimental treatment of hypothyroidism, the extract of the root of $R$. semenowii $\mathrm{B}$. with a predominant content of rhodioflavonoside has a pronounced therapeutic effect, expressed in the normalization of the level of pituitary and thyroid hormones. The obtained results indicate the absence of toxic and damaging effects such as activation and inhibition of hematopoiesis after enteral administration of the root extract of $R$. semenowii.
\end{abstract}

Keywords: hematology, hypothyroidism, thyroid, Rhodiola semenowii, extract, phytopreparation, medicinal plants, root.

\section{Introduction}

Thyroid pathology has a prime position in clinical endocrinology. Diseases of the thyroid gland in terms of prevalence share the priority with diabetes mellitus, far ahead of other endocrine disorders. Thyroid hormones (THs) that are synthesized and released by the thyroid are essential for normal growth, development, and metabolism of organisms, as well as energy homeostasis. Even small changes or an imbalance in thyroid homeostasis may adversely affect human health [1].

The methods of treatment are associated with the prescription of medications containing thyroid hormones; patients often do not adhere to treatment regimens. If the treatment is not adequate, then the patients might develop ischemic heart disease, disorders in reproductive system, and psychological disorders. With a high dose of hormones, myocardial dystrophy might develop and there might be changes in mineral composition of bone tissue [2]. Currently, the greatest prevalence and clinical significance are primary hypothyroidism caused by a defect in the biosynthesis of hormones T4 (and T3) due to disorders in the thyroid gland. Its frequency among the population is high: overt hypothyroidism $-0.2-2.0 \%$, subclinical - approximately $7-10 \%$ among women and men $2-3 \%$. In the group of older women, the prevalence of all forms of hypothyroidism can reach $12 \%$ or more (sporadic goiter). These data suggest that hypothyroidism is one of the most common endocrine diseases. Hypothyroidism might cause the development of complications from the cardiovascular, digestive, reproductive, and central nervous systems, and in case of decompensation, it might lead to death [3]. With a decrease in the function of the thyroid gland, changes in the hematopoietic system might occur [4]. Currently, it has been established that a deficiency of thyroid hormones leads to a qualitative and quantitative impairment of erythropoiesis [5]. It has been proven that low levels of thyroxine and thyroid teranine lead to impaired erythropoiesis, including a direct relationship between the erycitic index and the content of thyroid hormones in the blood [6]. Hypothyroidism has various effects on hematopoiesis, peripheral blood cells, and the coagulation system. $25-50 \%$ of patients with hypothyroidism suffer from anemia and concomitant diseases that develop with dysfunction of the thyroid gland [7]. The protocol for the treatment of thyroid disorders has not changed over the past 15 years, and the new offered drugs are not effective enough [8].

Herbal medicines, acting systemically on the body, regulate the functions of various interconnected systems and organs. They have almost no side effects, and can be used both for treatment and the prevention of various diseases [9]. Research illustrates that Rhodiola semenowii Boriss. stimulates the body's immune response, enhances cell proliferation in the central and peripheral organs of the immune system and weakens 
inflammatory damage in various diseases, regulating the differentiation of immune cells, activating inflammatory signaling pathways and releasing inflammatory factors [10]. Since stress factors with low immunity are the main causes of thyroid diseases, our main task is to conduct an experimental study by correcting (treating) primary hypothyroidism using an extract of the plant $R$. semenowii.

\section{Experimental}

The study material was the extract of the root of the plant $R$. semenowii both alone and in combination with potassium iodide. The experimental study was carried out in two stages on nonlinear white male rats (50 individuals) weighing 200-250 g. Animals were kept in cages in groups of 10 individuals. There were 4 groups of animals in total. Wood sawdust was used as a bedding. The air temperature in the premises of the vivarium was maintained in the range of $18-200{ }^{\circ} \mathrm{C}$ with a relative humidity of $60-70 \%$. The animals were kept under standard conditions on a vivarium diet. Animals were monitored daily applying an open field behavioral test and weighed. All experimental studies were conducted in accordance with the rules set out in the Guidelines for preclinical, biomedical, and clinical research in Kazakhstan (July 25, 2007, No. 442).

At the first stage, all animals were divided into 2 main groups: $1^{\text {st }}$ group - control, $2^{\text {nd }}$ group experimental hypothyroidism. The first group of animals received oral water (placebo) daily for 15 days. To simulate experimental hypothyroidism in the second group, the pharmaceutical drug "Mercazolil Health" ("Health" pharmaceutical company, Ukraine) was used. Daily mercazolil was administered orally at the rate of $2.5 \mathrm{mg}$ per $100 \mathrm{~g}$ of body weight for 15 days [11]. After creating an experimental model of hypothyroidism, a control study of the levels of TSH, free T4, free T3, and TG in the blood serum was carried out to confirm the development of the hypothyroidism state. At the second stage of the research, animals of the second group with confirmed hypothyroidism were divided into 3 subgroups: subgroup $2 \mathrm{a}-$ hypothyroidism model without treatment; subgroup $2 \mathrm{~b}$ - correction of hypothyroidism with an extract of $R$. semenowii root by enteral administration of the extract at the rate of $2.5 \mathrm{mg}$ per $100 \mathrm{~g}$ of body weight animal for 28 days; and subgroup 2c - correction of hypothyroidism with an extract of the root of $R$. semenowii by enteral administration of the extract at the rate of $2.5 \mathrm{mg}$ per $100 \mathrm{~g}$ of animal body weight in combination with potassium iodide at the rate of $1 \mu \mathrm{g}$ per $100 \mathrm{~g}$ of body weight for 28 days.

At the end of the experiment, peripheral blood was taken from all animals for hematological and immunochemical studies in vacutainers containing the K3-EDTA anticoagulant and a coagulation activator with a separating gel. Hematological tests were carried out on an automatic hematological analyzer Sysmex XS-550-i (Japan). Levels of TSH, free T4, free T3, and TG in blood serum to confirm the hypothyroid state were conducted on an automatic immunochemiluminescence analyzer "Immulite 2000XPi" Siemens (Germany). The obtained data were analyzed applying statistical methods in the Statistica-6.0 program. The significance of the arithmetic mean differences was assessed using the Student's t-test. P values $\leq 0.05$ were considered statistically significant.

\section{Results and Discussion}

According to the available chemical composition data, in the root extract of plant $R$. semenowii substances such as flavonoids $(74.8 \%)$, coumarins $(11.7 \%)$, phenolic acids $(6.1 \%)$, and polysaccharides $(7.4 \%)$ were identified. The main biologically active component of flavonoids was rhodioflavonoside. In the course of this study, the purpose was to determine changes in the general hematological parameters after correction of experimental hypothyroidism with an extract of the root of the plant $R$. semenowii both alone and in combination with potassium iodide. The results of the study of the comparative assessment of the hematological parameters of the observed groups are presented in Table 1.

In the Table, there were statistically significant differences $(p<0.001)$ between the hematological parameters of experimental animals, including the total number of leukocytes, the total number of erythrocytes, hemoglobin level, and the total number of platelets, but they were all within the physiological norm. Based on analysis of the hematological parameters of animals in groups $1,2 \mathrm{a}, 2 \mathrm{~b}$, and $2 \mathrm{c}$ the following data was illustrated: the hemoglobin content in animals with experimental hypothyroidism was $160.60 \pm 4.47 \mathrm{~g} / 1$ versus $146.00 \pm 4.06 \mathrm{~g} / \mathrm{l}$ in the control. Here, small relative changes can be noticed. When counting the number of red blood cells $7.06 \pm 0.58 \times 10^{12} / 1$, leukocytes $7.28 \pm 1.13 \times 10^{9} / 1$, and platelets $475.41 \pm 49.47 \times 10^{3} / 1$ in animals of subgroup $2 \mathrm{a}$ with experimental hypothyroidism, it was found that the arithmetic mean values of the amount of the above elements are normal and do not differ significantly from those of clinically healthy animals of the $1^{\text {st }}$ control group. The percentage of different types of leukocytes in animals of subgroup $2 \mathrm{a}$ did not change considerably in comparison with the leukogram of control animals. 
Small relative changes were also observed only in the content of lymphocytes in animals of subgroup 2a with experimental hypothyroidism $48.48 \pm 2.76 \%$ versus $40.40 \pm 2.30 \%$ in the control group.

$\mathrm{Tab} l \mathrm{e} 1$

Hematological parameters of the blood of rats of the intact group, with hypothyroidism and experimental treatment with the extract $R$. semenowii $B$. both alone and in combination with potassium iodide

\begin{tabular}{|c|c|c|c|c|c|}
\hline $\begin{array}{l}\text { Indicator name, } \\
\text { unit of measurement }\end{array}$ & $\begin{array}{c}\text { Internatio } \\
\text { nal } \\
\text { abbreviat } \\
\text { ion }\end{array}$ & $\begin{array}{l}\text { Control group } \\
\quad \text { (group 1) }\end{array}$ & $\begin{array}{c}\text { Experimental } \\
\text { Hypothyroidism } \\
\text { in no cure } \\
\text { (group 2a) }\end{array}$ & $\begin{array}{l}\text { Correction with } \\
\text { extract } R \text {. } \\
\text { semenowii } \\
\text { (group 2b) }\end{array}$ & $\begin{array}{c}\text { Correction } \\
\text { with extract } \\
R . \text { semenowii } \\
\text { in combination } \\
\text { with potassium } \\
\text { iodide } \\
\text { (group } 2 \mathrm{c})\end{array}$ \\
\hline Total number of Leukocytes, $10^{9} / 1$ & WBC & $6.22 \pm 0.44$ & $7.28 \pm 1.13$ & $7.64 \pm 1.19$ & $6.73 \pm 1.04$ \\
\hline Total Red Blood Cell Count, $10^{12} / 1$ & $\mathrm{RBC}$ & $6.29 \pm 0.52$ & $7.08 \pm 0,58$ & $7.81 \pm 0,65$ & $8.28 \pm 0.68$ \\
\hline Hemoglobin level, g/l & HGB & $146.00 \pm 4.06$ & $160.60 \pm 4.47 *$ & $157.39 \pm 4.38$ & $154.24 \pm 4.29$ \\
\hline Total platelet count, $10^{3} / 1$ & PLT & $413.40 \pm 43.02$ & $475.41 \pm 49.47$ & $570.49 \pm 59.3$ & $599.02 \pm 62.34$ \\
\hline Absolute neutrophil count $10^{9} / 1$ & Neut & $3.06 \pm 0.41$ & $3.03 \pm 0.54$ & $3.46 \pm 0.86$ & $2.55 \pm 0.80$ \\
\hline Absolute lymphocyte count $10^{9} / 1$ & Lymph & $2.51 \pm 0.14$ & $3.52 \pm 0.51$ & $3.53 \pm 0.72$ & $3.63 \pm 0.60$ \\
\hline Absolute content of monocytes $10^{9} / 1$ & Mono & $0.47 \pm 0.12$ & $0.52 \pm 0.23$ & $0.49 \pm 0.13$ & $0.26 \pm 0.04$ \\
\hline Absolute eosinophil content $10^{9} / 1$ & Eos & $0.16 \pm 0.05$ & $0.19 \pm 0.06$ & $0.12 \pm 0.08$ & $0,41 \pm 0.07 * * *$ \\
\hline The absolute content of basophils $10^{9} / 1$ & Baso & $0.3 \pm 0.01$ & $0.20 \pm 0.02$ & $0.04 \pm 0.01$ & $0.10 \pm 0.05$ \\
\hline The relative content of neutrophils $\%$ & Neut & $49.00 \pm 3.60$ & $41.58 \pm 4.66$ & $45.17 \pm 7.44 * *$ & $37.57 \pm 7.30 * * *$ \\
\hline The relative content of lymphocytes $\%$ & Lymph & $40.40 \pm 2.30$ & $48.48 \pm 2.76^{*}$ & $46.20 \pm 6.53 * *$ & $54.20 \pm 6.57$ \\
\hline The relative content of monocytes $\%$ & Mono & $7.56 \pm 1.77$ & $7.00 \pm 2.00$ & $6.56 \pm 1.86$ & $6.16 \pm 1.35$ \\
\hline The relative content of eosinophils \% & Eos & $2.55 \pm 0.96$ & $2.59 \pm 0.90$ & $1.60 \pm 1.14$ & $1.60 \pm 0.89$ \\
\hline The relative content of basophils \% & Baso & $0.49 \pm 0.05$ & $0.35 \pm 0.37$ & $0.47 \pm 0.09$ & $0.47 \pm 0.01$ \\
\hline
\end{tabular}

At the second stage of the study, after the application of the extract of $R$. semenowii, correcting hypothyroidism, alone and in combination with potassium iodide, the following picture was observed: the hemoglobin level in subgroups $2 \mathrm{~b}$ and $2 \mathrm{c}$ did not demonstrate changes. The number of leukocytes showed insignificant changes in subgroup $2 \mathrm{~b}\left(7.64 \pm 1.19 \times 10^{9} / \mathrm{L}\right)$ compared to subgroup $2 \mathrm{a}$, while in subgroup $2 \mathrm{c}$ it did not show any considerable changes. The level of erythrocytes was considerably increased in subgroup $2 \mathrm{c}$ $\left(8.31 \pm 0.68 \times 10^{9} / \mathrm{L}\right)$, which indicates the restoration of erythropoiesis. The number of platelets in subgroup $2 \mathrm{~b}$ was $570.49 \pm 59.3 \times 10^{3} / 1$, and in subgroup $2 \mathrm{c}-599.02 \pm 62.34 \times 10^{3} / 1$. There are no significant changes in this parameter.

According to the results of some researchers [11-13] on the study of blood parameters in pathologies of the thyroid gland, the number of erythrocytes in simulated hypothyroidism decreases. In addition, on this background, the hemoglobin content decreases by $4.65 \%$ in hypothyroid animals which leads to the development of anemia [14]. In our study, evaluation of the hemoglobin content in animals with hypothyroidism, in comparison with healthy animals, did not detect any significant changes. When calculating the number of erythrocytes, leukocytes, and platelets in animals with hypothyroidism, a number of authors [11-14] designated that the average values of the named, shaped elements were within the norm range, not significantly differing from similar indicators of clinically healthy rats, which is consistent with the results of this study [12]. In studies of experimental hypothyroidism, when assessing the rate of erythropoiesis, it was found that mercazolil inhibits the maturation of erythrocytes [13]. However, with short-term modeling of the hypothyroid state, the function of erythropoiesis is preserved.

When assessing the biological effects of iodine-containing preparations in accordance with researchers [11], the number of erythrocytes in individuals receiving "iodovet" increased, in relation to the group with hypothyroidism, by $8 \%$, and the hemoglobin level - by $2.7 \%$, which indicates the restoration of erythropoiesis [14]. When assessing hematological parameters, the total number of leukocytes and platelets in the compared groups did not change significantly. The studied iodine-containing diets contributed to the restoration of the level of blood cells [12]. In hormone replacement therapy with thymazole, stimulation of 
erythropoiesis takes place due to an increase in the production of erythropoietin, but the actual hematological changes after reaching euthyroidism are not eliminated [13]. The administration of levothyroxine in hypothyroidism contributes to the correction of hemogram parameters and the acceleration of iron metabolism in the body of animals. In addition, when using thyroid hormones in hypothyroidism therapies, it was shown that an increase in animal body weight reduced the effectiveness of treatment. Good therapy results were obtained in microcytosis, iron deficiency, hypochromic anemias [11].

\section{Conclusions}

As a result of the study, it was identified that in the experimental treatment of hypothyroidism, an extract of the root of $R$. semenowii with a predominant content of rhodioflavonoside (up to $70 \%$ ) has a pronounced therapeutic effect, expressed in the normalization of the level of pituitary and thyroid hormones. Furthemore, the obtained data indicate the absence of toxic and damaging effects such as activation and inhibition of hematopoiesis after enteral administration of the root extract of $R$. semenowii $B$. Based on this, an extract of the root of $R$. semenowii with a predominant content of rhodioflavonoside (up to $70 \%$ ) in combination with potassium iodide is recommended for further extended study as a means of correcting pathological conditions associated with a decrease in thyroid function.

\section{References}

1 Zhang P. P38/TRHr-Dependent Regulation of TPO in Thyroid Cells Contributes to the Hypothyroidism of Triclosan-Treated Rats / P. Zhang, M. Yang, L. Zeng, C. Liu // Cellular Physiology and Biochemistry. — 2018. — Vol. 45, № 4. — P. $1303-1315$. https://doi.org/10.1159/000487558

2 Louzada R.A. Similarities and Differences in the Peripheral Actions of Thyroid Hormones and Their Metabolites / R.A. Louzada, D.P. Carvalho // Front. Endocrinol. — 2018. — Vol. 9. — P. 394. https://doi.org/10.3389/fendo.2018.00394

3 Yao Z. Relation of Gut Microbes and L-Thyroxine Through Altered Thyroxine Metabolism in Subclinical Hypothyroidism Subjects / Z. Yao, M. Zhao, Y. Gong, W. Chen, Q. Wang, Y. Fu, T. Guo, J. Zhao, L. Gao, T. Bo // Front. Cell. Infect. Microbiol. 2020. — Vol. 10. - P. 495. https://doi.org/10.3389/fcimb.2020.00495

4 Yang N. Novel Clinical Evidence of an Association between Homocysteine and Insulin Resistance in Patients with Hypothyroidism or Subclinical Hypothyroidism / N. Yang, Z. Yao, L. Miao, J. Liu, X. Gao, H. Fan // PLoS ONE. — 2015. — Vol. 10 (5); Article ID e0125922. https://doi.org/10.1371/journal.pone.0125922

5 Sikandar H.K. Association of metabolic risks with subclinical hypothyroidism: A crosssectional analysis / H.K. Sikandar, S.M. Manzoor, N.K. Niazi, N. Asif, A. Ijaz, N. Fazal. // Pak J Med Sci. — 2018. — Vol. 34, № 2. - P. 357-362. https://doi.org/10.12669/pjms.342.13873

6 Ordookhani A. Hemostasis in Overt and Subclinical Hyperthyroidism / A. Ordookhani, K.D. Burman // Int J Endocrinol Metab. — 2017. — 23, 15 (3); Article ID e44157. https://doi.org/10.5812/ijem.44157

7 Современная диагностика и лечение гипетиреоза. Электронный ресурс. Режим доступа: https://www.lvrach.ru. (Дата обращения: 15.01.2020).

8 Dignass A.U. European consensus on the diagnosis and management of iron deficiency and anemia in inflammatory bowel diseases / A.U. Dignass, C. Gasche, D. Bettenworth // J Crohns Colitis. — 2015. — Vol. 9 (3). — P. 211-22. https://doi.org/10.1093/ ecco-jcc/jju009

9 Mendes D. Prevalence of Undiagnosed Hypothyroidism in Europe: A Systematic Review and Meta-Analysis / D. Mendes, C. Alves, N. Silverio, F. Batel Marques // European Thyroid Journal. — 2019. — P. 1-14. https://doi.org/10.1159/000499751

10 Mukherjee S. Prevalence of Subclinical Hypothyroidism in Acute Coronary Syndrome in Nondiabetics: Detailed Analysis from Consecutive 1100 Patients from Eastern India / S. Mukherjee, S. Datta, S.C. Mandal // Journal of Thyroid Research. — 2018. - P. 1-4. https://doi.org/10.1155/2018/9030185

11 Колесников С.И. Нарушение тиреодного статуса, процессов липопериоксидации и структуры гепатоцитов при экспериментальном гипотериозе / С.И. Колесников, Н.Г. Макарова // Сиб. мед. журн. — 2014. — № 4. — С. 18-24.

12 Решетников В.Н. Государственная народножизненная программа развития сырьевой базы и переработки лекарственных и пряно-ароматических растений на 2005-2010 годы / В.Н. Решетников // Фитопрепараты - инновации в действии. - Минск, 2010. - С. 12-18.

13 Рахимова Г.О. Влияние экстракта родиолы Семенова на иммунную систему и на физические способности организма / Г.О. Рахимова, 3.Т. Файзяева // Универсум: химия и билогия. — 2020.

14 Глумова В.А. Структурные изменения при адаптивно-компенсаторных реакциях щитовидной железы / В.А. Глумова, И.А. Черенков, Н.Н. Чучкова // Морфология. - М.: Медицина, 2002. — С. 58-112. 


\title{
Н.К. Корбозова, Т.Н. Кобулина, Н.О. Кудрина, Н.В. Терлецкая, А.К. Шокан \\ Rhodiola semenowii сығындысының эксперименттік гипертериоздағы гематологиялық көрсеткіштерге әсері
}

\begin{abstract}
Қалқанша безінің патологиясы клиникалық эндокринологияда маңызды рөл атқарады. Қалқанша безінің аурулары таралуы бойынша басқа эндокриндік ауытқулардан гөрі қант диабетімен бірдей басымдықты көрсетеді. Қазіргі таңда қолданылатын гипотиреозды емдеу тәсілдері патогенезге тәуелді болмайды және гормонды алмастыру терапиясына әкеледі. Осы зерттеуді орындау барысында қойылған міндет - $R$. semenowii өсімдігінің тамырын жеке және калий йодидімен қосылған сығындысын гипотиреозды емдеуге қарсы қолдана отырып, оның жалпы гематологиялық көрсеткіштерін анықтау. Зерттеу материалы $R$. semenowii өсімдігінің тамырының сығындысы. Осылайша жүргізілген зерттеулердің нәтижесі көрсеткендей, $R$. semenowii өсімдігінің тамырынан жасалған сығынды тәжірибелі гипотиреозды өздігінен немесе калий йодид қосылған сығындысы болса да жақсы ықпал ететіндігі байқалды. R. semenowii өсімдігінің тамырының сығындысы қалқанша безі мен гипофиздің гормондар деңгейін қалыпқа келтіреді. Сонымен алынған нәтижелердің сараптамасына сүйенсек, $R$. semenowii өсімдігінің тамырының сығындысын ішке ауыз арқылы енгізгенде гемопоезға ешқандай зиянды ықпалының жоқтығы байқалды.
\end{abstract}

Кiлm сөздер: гематология, гипертериоз, қалқанша без, Rhodiola semenowii, сығынды, фитопрепарат, дәрілік өсімдік, тамыр.

Н.К. Корбозова, Т.Н. Кобулина, Н.О. Кудрина, Н.В. Терлецкая, А.К. Шокан

\section{Влияние экстракта Rhodiola semenowii на гематологические показатели при экспериментальном гипертериозе}

\begin{abstract}
Патология щитовидной железы занимает лидирующую позицию в клинической эндокринологии. По встречаемости нарушения щитовидной железы сравнимы с сахарным диабетом, таким образом, они намного опережают другие эндокринные заболевания. В настоящее время принципы, которых придерживаются при коррекции гипотиреоза, практически не учитывают патогенез заболевания и, в основном, включают заместительную гормональную терапию. В ходе выполнения данного исследования была поставлена задача - определить общие гематологические показатели после коррекции экспериментального гипотиреоза экстрактом корня растения $R$. semenowii, как самостоятельного, так и в сочетании с калием йодида. Материалом исследования послужил экстракт корня растения $R$. semenowii, как самостоятельно, так и в сочетании с калием йодида. В результате проведенных исследований было установлено, что в экспериментальном лечении гипотиреоза экстракт корня $R$. semenowii оказывает выраженный терапевтический эффект, проявляющийся в нормализации уровня гормонов гипофиза и щитовидной железы. Полученные данные свидетельствуют об отсутствии токсических и повреждающих эффектов в виде активации/угнетения гемопоэза при энтеральном введении экстракта корня $R$. semenowii.
\end{abstract}

Ключевые слова: гематология, гипертериоз, щитовидная железа, Rhodiola semenowii, экстракт, фитопрепарат, лекарственное растение, корень.

\section{References}

1 Zhang, P., Yang, M., Zeng, L., \& Liu, C. (2018). P38/TRHr-Dependent Regulation of TPO in Thyroid Cells Contributes to the Hypothyroidism of Triclosan-Treated Rats. Cellular Physiology and Biochemistry, 45 (4), $1303-1315$. https://doi.org/10.1159/000487558

2 Louzada, R.A., \& Carvalho, D.P. (2018). Similarities and Differences in the Peripheral Actions of Thyroid Hormones and Their Metabolites. Front. Endocrinol., 9, 394. https://doi.org/10.3389/fendo.2018.00394

3 Yao, Z., Zhao, M., Gong, Y., Chen, W., Wang, Q., \& Fu, Y., et al. (2020). Relation of Gut Microbes and L-Thyroxine Through Altered Thyroxine Metabolism in Subclinical Hypothyroidism Subjects. Front. Cell. Infect. Microbiol., $10,495$. https://doi.org/10.3389/fcimb.2020.00495

4 Yang, N., Yao, Z., Miao, L., Liu, J., Gao, X., \& Fan, H. (2015). Novel Clinical Evidence of an Association between Homocysteine and Insulin Resistance in Patients with Hypothyroidism or Subclinical Hypothyroidism. PLoS ONE, 10 (5), e0125922. https://doi.org/10.1371/journal.pone.0125922

5 Sikandar, H.K., Manzoor, S.M., Niazi, N.K., Asif, N., Ijaz, A., \& Fazal, N. (2018). Association of metabolic risks with subclinical hypothyroidism: A crosssectional analysis. Pak J Med Sci., 34 (2), 357-362. https://doi.org/10.12669/pjms.342.13873 
6 Ordookhani, A., \& Burman, K.D. (2017). Hemostasis in Overt and Subclinical Hyperthyroidism. Int J Endocrinol Metab., 15(3), e44157. https://doi.org/10.5812/ijem.44157

7 (2020). Svoevremennaia diagnostika i lechenie gipotireoza [Modern diagnostics and treatment of hypothyroidism]. Retrieved from: https://www.lvrach.ru (Date of application: 15.01.2020) [in Russian].

8 Dignass, A.U., Gasche, C., \& Bettenworth, D. (2015). European consensus on the diagnosis and management of iron deficiency and anemia in inflammatory bowel diseases. J Crohns Colitis, 9, 3, 211-22. https://doi.org/10.1093/ecco-jcc/jju009

9 Mendes, D., Alves, C., Silverio, N., \& Batel Marques, F. (2019). Prevalence of Undiagnosed Hypothyroidism in Europe: A Systematic Review and Meta-Analysis. European Thyroid Journal, 1-14. https://doi.org/10.1159/000499751

10 Mukherjee, S., Datta, S., \& Mandal, S.C. (2018). Prevalence of Subclinical Hypothyroidism in Acute Coronary Syndrome in Nondiabetics: Detailed Analysis from Consecutive 1100 Patients from Eastern India. Journal of Thyroid Research, 1-4. https://doi.org/10.1155/2018/9030185

11 Kolesnikov, S.I., \& Makarova, N.G. (2014). Narusheniia tireoidnogo statusa, protsessov lipoperioksidatsy i struktury gepatotsitov pri experimentalnom gipotireoze [Disorders of thyroid status, lipid peroxidation processes and hepatocyte structure in experimental hypothyroidism]. Sibirskii meditsinskii zhurnal - Siberian Medicinal Journal, 4; 18-24 [in Russian].

12 Reshetnikov, V.N. (2010). Gosudarstvennaia narodokhoziaistvennaia programma razvitiia syrevoi bazy i pererabotki lekarstvennykh i priano-aromaticheskikh rastenii na 2005-2010 gody. Fitopreparaty - innovatsii v deistvii [State national economic program for development of raw materials base and processing of medicinal and spicy-aromatic plants for 2005-2010 "Phytopreparations" - innovation in action. Minsk [in Russian].

13 Rahimova, G.O., \& Faizyeva, Z.T. (2020). Vliianie ekstrakta rodioly Semenova na imunnuiu sistemu i na fizicheskuiu rabotosposobnost organizma [Effect of Rhodiola semenov extract on the immune system and on the physical performance of the body]. Universum: khimiia i biologiia - Universum: Chemistry and Biology [in Russian].

14 Glumova, V.A., Cherenkov, I.A., \& Chuchkova, N.N. (2002). Strukturnye izmeneniia pri adaptivno-kompensatornykh reaktsiiakh shchitovidnoi zhelezy [Structural changes in adaptive-compensatory thyroid responses]. Morfologiia - Morphology. Moscow [in Russian]. 